\title{
Teaching with Iwbs in Abu Dhabi Public Schools
}

\author{
Dr Olga Samsonova \\ Higher Colleges of Technology
}

\begin{abstract}
The sole objective of this research was to assess Abu Dhabi public school teachers' standpoints on interactive whiteboards (IWBs) and how this technology is utilised in the classroom environment. This study was organised at the Teacher Training Institute in Abu Dhabi, UAE, during a professional development session in January 2019. One hundred twentythree educators (Grades K-12) from several public schools completed structured pre and posttraining surveys and were members of group discussions. The outcome of this research underlined an overall optimistic attitude and a great deal of satisfaction among most of the educators towards IWBs. Organising lessons, teaching, engaging, and motivating students, with the assistance of IWBs, all appeared to be valuable for public school teachers. The study emphasised the main advantages and recommendations for professional development sessions on IWBs to be further useful for the educators' practice.
\end{abstract}

KEYWORDS: Interactive whiteboards, public school teachers, technology, professional development sessions, assessing with technology

\section{INTRODUCTION}

The distribution of innovative technology potentially into all aspects of Education to improve educational outcomes is an ongoing process. Moreover, interactive whiteboards (IWB) are rapidly incorporated within school settings, replacing black or whiteboards. The main contributors to this process are teachers who are responsible for linking the technology integration process to pedagogy. Thus, it is incredibly crucial to understand teachers' perceptions of the IWBs and provide them with support, training, and collaboration (Samsonova, 2018; 2019). The present research investigates Abu Dhabi's public school teachers' perceptions and classroom practices with IWBs. The study traces the experiences of educators teaching in different grades and teaching different subjects (Math, English, Arabic, Science, Social Studies, and Technology) (Samsonova, in press).

\section{IWBS IN THE EMIRATE OF ABU DHABI}

Educational technology, such as IWB, tablet PC, and iPad, is increasingly recognised and widely introduced in private and public schools in the United Arab Emirates (UAE). New technologies are being used in growing numbers of schools. A few years ago, Abu Dhabi Educational Council (ADEC) announced the launching of the New School Model (NSM), 


\section{2nd International Conference on \\ New Trends in Teaching and Education}

29-31 October, 2020

London, United Kingdom

NEW TRENDS

IN TEACHING

AND EDUCATION

which aimed to improve the education system in the emirate (Abu Dhabi Education Council, 2016). The model was based on technology, a resource-rich environment, and a student-centred approach. E-learning was announced as a fundamental approach towards successful teaching and learning that needed to be aligned with the Abu Dhabi Economic Vision 2030, where ICT skills play an essential role as a foundation for more advanced knowledge. In the NSM, ADEC proposed that educators continuously find new ways of using technology and eLearning in the classroom. IWBs are part of developmentally-appropriate technology and tools that can enhance other educational resources.

Many studies have been conducted about the use of IWBs in classrooms and schools worldwide. However, after extensive review, it has been found that there is very little said about using IWBs in UAE. Most studies are focused on a higher education perspective (AlQirim, 2016). Besides, Abu Dhabi schools in general and public schools, in particular, were not widely studied in terms of IWB usage. Since Abu Dhabi public schools are unique, the results of the current study might be impressive for other public schools in the UAE and probably other Middle Eastern countries.

\section{LITERATURE REVIEW}

The existing research highlighted that digital learning in the classroom promotes positive social norms and learner-centred pedagogy. IWBs provide many advantages for students and teachers. For them, it offers high-level interactivity in the classroom (Tosuntaş, Karadağ, \& Orhan, 2015). Murcia's (2014) exploratory case study examined the types of interactivity that occur when IWBs are used during the science inquiry process. In this research, two Australian teachers worked with 25 eleven-year-old students developing and implementing interactive pedagogies and notebooks. The video and classroom observations data allowed the researchers to classify the types of interactivities occurring in the classroom: (a) technical interactivity (when teachers used the IWB tools); (b) physical interactivity (when students manipulated objects on the IWB); and (c) conceptual interactivity (when students and teachers aligned their actions with the given IWB task and engaged in classroom dissociation).

Once the teachers in the study used IWB for the science lessons, students were passive, watching videos or listened to the teacher. Another time, the teachers involved students in whole-class discussions and checked their understanding through recording made on IWBs. It has been concluded that IWBs support teaching and learning experiences by: (a) engaging and eliciting learners' prior knowledge through conceptually appealing and visually multimodal interactive displays; (b) generating explanation and exploration opportunities; (c) providing opportunities through higher-level questioning for learners to transfer their knowledge to different and new contexts; (d) creating opportunities for students to generate their concept representations; and (e) reviewing learning by flexibly moving throughout interactive learning sequences. 


\section{2nd International Conference on \\ New Trends in Teaching and Education}

IWBs enhance the social and subject interactions between students and teachers (Mata, Lazar, \& Lazar, 2016). For example, Hadadi, Abbasi, and Goodarzi (2014) studied the pedagogical practice of 11 teachers from two different schools. They explored the teachers' educational needs as they integrated IWBs into the curriculum. The research suggested that students' collaboration occurred through complex web interactions between the IWB affordances and that the teachers play the role of mediators and task designers. The authors underlined the IWBs value in creating an appropriate environment for a shared understanding between students and teachers. To conclude, IWBs facilitate the collective meaning-making process inclass work (Mellingsaeter \& Bungum, 2015).

IWBs and information technologies, in general, lead to an increase in students' motivation and it encourages their attention (Arpacık, Kurşun, \& Göktaş, 2018). IWBs users highlight the positive and negative sides of IWBs usage (Tertemiz et al., 2015). Mostly, teachers and students are satisfied and have positive attitudes towards IWBs (Bakadam \& Asiri, 2012). The use of IWBs supports teachers by helping them enhance students' concentration, active learning, creativity, and engagement (Erbas, Ince, \& Kaya, 2015). Also, IWBs might make a big difference in learners' achievement (Tunaboylu and Demir, 2017).

Alshawareb and Abu Jaber (2012) found that there were no significant differences between teachers' attitudes according to gender and specialisation, such as the art and science fields. However, educators with more than 15 years of experience hold firmer positive beliefs than teachers with five years of experience. Lecturers holding higher degrees, such as MA or Ph.D., tend to have more positive thoughts toward IWBs and use them more frequently than educators with lower education levels (Samsonova 2018; 2019). It has been found that some teachers experienced problems related to a lack of pedagogical knowledge, issues with technical skills, and access to materials required for efficient IWB use (Korkmaz \&Cakil, 2013).

IWBs are most beneficial if the teachers know how to use technology (Bourbour, Vigmo, \& Samuelsson, 2015; Erbas, Ince, \& Kaya, 2015). Educators require specialised training to prepare materials needed for IWB usage (Korkmaz \&Cakil, 2013). However, insufficient numbers of professional development classes and experts in schools for immediate technical assistance with IWB challenges pose problems with implementation (Akkoyunlu \& Baskan, 2015). As a solution to this problem, Türel and Johnson (2012) suggested a collaboration with colleagues. To conclude, professional development has been found as the most efficient way for IWB technology integration (Hennessy, Haßler \& Hofmann, 2015; Peled, Medvin, \& Domanski, 2015).

\section{RESEARCH METHODOLOGY}

\subsection{Overview}

The site of the study was a Teacher Training Institute in Abu Dhabi, UAE. The UAE Ministry of Education (MoE) offers professional development forums for teachers working in government schools. These typically last one week and include several 2-hour professional development (PD) sessions on different topics that can be chosen by teachers based on their 
priorities. One of the teachers' forums occurred in January 2019. The PD session entitled "Education Technology: Teaching with Interactive Whiteboards (IWBs)" was offered during the morning block. At the beginning of the PD, it was announced that PD participants had an opportunity to take part in a study on IWBs.

\subsection{Participants}

Out of 167 teachers that chose the PD session on IWBs, 123 agreed to be study participants. The contributors were teachers (Grades K-12) from several public schools of the Abu Dhabi Emirate, UAE.

\subsection{Research questions}

The study aimed to answer the following questions:

- How can IWBs be used in classrooms?

- How do IWBs affect the planning/preparation of lessons?

- How can IWBs be used to ensure that all children are motivated and engaged in learning?

- How can IWBs be used for assessing students' learning?

- To what extent was the PD session on IWB useful for your future professional activities?

\subsection{Data collection tools}

A combination of qualitative and quantitative approaches was used to collect data needed to answer the research questions. The instruments included questionnaires with closed and openended questions that were created based on the research questions, the literary review, and the researcher's experience in the field.

\subsection{Data analysis}

SPSS software was used to examine the data from the questionnaires and discussions. A weighted average was obtained for questions with a five-point Likert Scale. Further, data collected from discussions were analysed, applying the phenomenographic approach that can be used to classify participants' expressions according to differences and similarities (Levin \& Wadmany, 2006).

\section{RESULTS AND DISCUSSION}

\subsection{Teachers' views of IWBs}

Teachers were given the opportunity to express their levels of satisfaction with IWBs. They found IWBs to have an impact on: (a) student learning, engagement, and motivation and (b) classroom interactions. They also believed that IWBs are useful in teaching. These outcomes are similar to views expressed in other studies where it is articulated that teachers perceived IWBs as a user-friendly tool that makes significant contributions to teaching practices (Davis, 2018). Hence, the use of the IWBs provided for whole-class learning with the students' interactions where the teacher played the facilitator's role (Berson et al., 2014). Moreover, IWBs serve as instructional enrichments that facilitate active learning engagement in a learner- 


\section{2nd International Conference on \\ New Trends in Teaching and Education}

29-31 October, 2020

London, United Kingdom

NEW TRENDS

IN TEACHING

AND EDUCATION

centred environment (Samsonova 2018; 2019). Comparing traditional and innovative schools, De Koster, Volman, and Kuiper (2013) provided examples of the IWBs being used to support whole-class teaching with active students' role in controlling the classroom dialogue as well as the IWBs content. It was concluded that it is essential for teachers to integrate the IWBs with pedagogy and learning theory that caters to students' individual needs to guide the learners' academic achievement (Katwibun, 2014).

\subsection{IWBs applications in classrooms}

In the pre-training surveys and discussions, most teachers stated that they use IWBs every day. In general, the educators identified the following as the most common ways to use interactive whiteboards in their classrooms: (a) as a projector; (b) as a typical classroom board; (c) for students' presentations; (d) for differentiation; (e) for classroom management; and (f) for whole and small group interactions. One of the participants explained, differentiation activities based on students' needs can be supported by IWBs as well. Additionally, the DoJo website was mentioned by multiple participants as the most useful behaviour management system; some participants stated that it is a school requirement to use Dojo for behaviour and teacher-parent communications.

Previous studies also mentioned that many instructors do not use the full potential of IWBs. Most teachers use IWBs for Internet research and as overhead projectors, avoiding many other advantageous IWB features because of limited IWB technology knowledge (Bakadam \& Asiri, 2012). There are connections between being the right ICT user and using IWB regularly in the classroom (Šumak et al., 2017). In order to overcome this problem, teachers required specialised IWB training and preparation of materials needed for the IWB usage; for example, videos, presentations, and visuals related to the state curriculum (Korkmaz \& Cakil, 2013). These conclusions were supported in a study by Rosetti (2012), where IWBs were used more often when offered with ready-made lessons. Consequently, the researcher suggested the development of resources such as ready-made lessons and websites where teachers could download and post lessons to support the integration of IWBs into classrooms. Other similar findings were: (a) using IWB for differentiated learning since several learning styles can be addressed incorporating IWBs (Samsonova 2018; 2019); (b) incorporating classroom management software in teaching (Samsonova, 2018); and (c) using IWBs for whole and small group interactions (Mellingsaeter \& Bungum, 2015). IWBs might help to minimise teachertalking time, improving some student skills such as discussions and teamwork (Arpacik, Kurşun, \& Göktaş, 2018).

A surprising finding was that many participants mentioned that their students create their own PowerPoints and present them on IWBs, converting the classroom into a student-centred space. Similar conclusions were made in another research study (Samsonova, 2018). Studying the elementary teachers' uses and perceptions about IWBs, the author found that meeting $21^{\text {st }}$ 


\section{2nd International Conference on \\ New Trends in Teaching and Education}

29-31 October, 2020

London, United Kingdom

NEW TRENDS

IN TEACHING

AND EDUCATION

century expectations educators try to become advocates of new educational techniques and incorporate more and more student-centred teaching strategies with IWBs.

\subsection{School support}

After answering the pre-training survey questions and participating in a discussion about IWB usage, some of the participants mentioned that they do not have IWBs in their classrooms or that their IWBs are not interactive. Also, there were two opposite opinions about school and administrative support. Some teachers stated that they have support. However, there were thoughts about some difficulties in obtaining assistance in school.

Supporting these findings, current research states that most educators insisted on the need to have training seminars, troubleshooting guides, or whiteboard tutorials to help them get the most out of IWB technology (Samsonova 2018; 2019). Educational technologists that supervise and support teachers' proficiency at all levels of IWB usage are needed (Korkmaz \& Cakil, 2013), and institutional support is required and mentioned the importance of immediate technical assistance (Tertemiz et al., 2015).

\subsection{Engaging and motivating students with IWBs}

The use of IWBs supports teachers by helping to enhance the students' motivation, participation, and concentration levels as well as increasing the frequency of interactions among students and teachers, and between the students within the classroom (Yang \& Teng, 2014). For example, Erbas, Ince, and Kaya (2015) explored the effects of using the NuCalc graphing software and IWBs compared to the traditional direct instruction-based environments on learners' achievements and attitudes toward technology and mathematics. Sixty-five high school graduates participated in this study. They found that students were motivated to learn materials and engaged with learning tasks when IWBs were used. They indicated that students were more attentive in class when the IWBs were used. Students liked the most about IWBs: (a) visual presentation; (b) test-based; (c) time saving; (d) hygiene; (e) multi-media; and (f) better learning (Arpacık, Kurşun, \& Göktaş, 2018). Furthermore, interactivity was named the most significant property of the IWB. A description of discovered approaches on students' engagement and motivation with IWBs based on the third research question included: (a) display motivating and engaging activities on the board; (b) make lessons interactive; (c) use learning games, differentiated tasks, competitions and rewards, and other exciting information; (d) use a behaviour management system; and (e) make the classroom more student-centred using IWBs.

\subsection{Assessments with IWBs}

In the pre-training surveys and discussions, the teachers showed their interest in incorporating the use of IWBs into assessment practice in several ways. In general, they believe that IWB's affordances offer a proper channel to assess learners efficiently and smoothly. Several websites that can be used for the assessments on IWBs were shared during 
PDs. However, even though many surveys indicated the use of various techniques to asses with IWBs, some of the study participants mentioned that they have no time to asses or do not use this option at all.

\subsection{PD on IWBs: Key benefits}

Post-training survey results indicate teachers' perceptions of the various benefits resulting from a professional development session on IWBs. The results are detailed below:

- The PD caused participants to reflect on the ways of using IWBs and offered new methods.

- The PD offered a review of grade and age-appropriate interactive strategies using IWBs and interactive tools.

- $\quad$ The PD and the discussion presented new ways to evaluate and plan with IWBs.

- $\quad$ The PD kept everyone engaged.

- $\quad$ During the PD session, participants had an opportunity to collaborate with fellow teachers.

- The PD and the discussion have helped to realise how to make everyday lessons more efficient.

- $\quad$ The PD inspired teachers to incorporate more IWBs activities through lessons.

- $\quad$ All great websites and ideas shared would be implemented in the future classroom.

$\bullet$

\section{CONCLUSION}

The main focus of this research study was to evaluate Abu Dhabi public school teachers' perceptions and usage of IWBs as well as the usefulness of PD sessions on IWBs. The findings highlighted mostly positive associations with IWBs, offered significant approaches for using IWBs in teaching and learning, and pointed to some key benefits and suggestions on how to make PD sessions on IWBs more meaningful and productive for teacher practice. Future studies using an experimental design are needed based on PD suggestions offered in this study by the teacher participants. Likewise, Hennessy (2017) conducted a literature review on teachers' experience and strategies with IWBs and concluded that there is no systematic analysis of the effectiveness of professional development sessions in terms of supporting IWB integration.

\section{REFERENCES}

ADEK. New School Model [online] https://www.adek.abudhabi.ae/en/Students/PS/Pages/New-School-Model.aspx (Accessed 10 May 2019).

Akkoyunlu, B. and Baskan, G., 2015. School principals' opinions on the FATIH Project in Turkey. Procedia-Social and Behavioral Sciences, 174, pp.1497-1502.

Al-Qirim, N., 2016. Smartboard technology success in tertiary institutions: The case of the UAE University. Education and Information Technologies, 21(2), pp.265-281. 


\section{2nd International Conference on \\ New Trends in Teaching and Education}

Alshawareb, A. and Abu Jaber, M., 2012. Teachers' attitudes toward using interactive whiteboards in the teaching and learning process in Jordan. International Journal of Instructional Media, 39(4).

Arpacık, Ö., Kurşun, E. and Göktaş, Y., 2018. Using interactive whiteboards as an assistive technology for students with intellectual disability. Journal of Education and Future, (14), pp.1-14.

Bakadam, E. and Asiri, M.J.S., 2012. Teachers' perceptions regarding the benefits of using the interactive whiteboard (IWB): The case of a Saudi intermediate school. Procedia-Social and Behavioral Sciences, 64, pp.179-185.

Berson, I., Cross, M., Ward, J. and Berson, M., 2014. People, places, and pandas: Engaging preschoolers with interactive whiteboards. Social Studies and the Young Learner, 26(4), pp.1822.

Bourbour, M., Vigmo, S. and Samuelsson, I.P., 2015. Integration of interactive whiteboard in Swedish preschool practices. Early Child Development and Care, 185(1), pp.100-120.

Davis, J.W., 2018. The educational contribution of interactive whiteboards. International Journal of Conceptual Structures and Smart Applications (IJCSSA), 6(1), pp.63-76.

De Koster, S., Volman, M. and Kuiper, E., 2013. Interactivity with the interactive whiteboard in traditional and innovative primary schools: An exploratory study. Australasian Journal of Educational Technology, 29(4).

Erbas, A.K., Ince, M. and Kaya, S., 2015. Learning mathematics with interactive whiteboards and computer-based graphing utility. Journal of Educational Technology \& Society, 18(2), pp.299-312.

Hadadi, A., Abbasi, H. and Goodarzi, A., 2014. Developing competencies for using the interactive whiteboard to implement communicative language teaching in the English (foreign language) classroom. Procedia-Social and Behavioral Sciences, 98, pp.618-620.

Hennessy, S., 2017. International experiences with integrating interactive whiteboards: Policy, practice, pedagogy and professional development. Life in Schools and Classrooms (pp. 633650). Springer, Singapore.

Hennessy, S., Haßler, B. and Hofmann, R., 2015. Challenges and opportunities for teacher professional development in interactive use of technology in African schools. Technology, pedagogy and Education, 24(5), pp.1-28.

Katwibun, H., 2014. Using an interactive whiteboard in vocabulary teaching. Procedia-Social and Behavioral Sciences, 116, pp.674-678.

Korkmaz, O. and Cakil, I., 2013. Teachers' difficulties about using smartboards. ProcediaSocial and Behavioral Sciences, 83, pp.595-599.

Levin, T. and Wadmany, R., 2006. Teachers' beliefs and practices in technology-based classrooms: A developmental view. Journal of Research on Technology in Education, 39(2), pp.157-181.

Mata, L., Lazar, G. and Lazar, I., 2016. Effects of study levels on students' attitudes towards interactive whiteboards in higher Education. Computers in Human Behavior, 54, pp.278-289. 


\section{2nd International Conference on \\ New Trends in Teaching and Education}

Mellingsaeter, M.S. and Bungum, B., 2015. Students' use of the interactive whiteboard during physics group work. European Journal of Engineering Education, 40(2), pp.115-127.

Murcia, K., 2014. Interactive and multimodal pedagogy: A case study of how teachers and students use interactive whiteboard technology in primary science. Australian Journal of Education, 58(1), pp.74-88.

Peled, Y., Medvin, M. and Domanski, L., 2015. Integrating IWB use in Western PA K-12 school districts: The professional development connection. Journal of Interactive Learning Research, 26(3), pp.289-305.

Rosetti, J., 2012. Analysing the perceptions and use of interactive whiteboards by prekindergarten teachers in the presentation of classroom lessons (Doctoral dissertation, Walden University).

Samsonova, O., (in press).Educational technology in Abu Dhabi public schools: Teaching with interactive whiteboards (IWBs). International Journal of Technology Enhanced Learning

Samsonova, O., 2018. Elementary teachers' uses and perceptions of interactive whiteboards for instruction. International Journal of Learning, Teaching and Educational Research, 17(8), pp.17-35.

Samsonova, O., 2019. Exploring elementary teachers' practices with a response to IWBs. PUPIL: International Journal of Teaching, Education and Learning, 3(1).

Šumak, B., Pušnik, M., Heričko, M. and Šorgo, A., 2017. Differences between prospective, existing, and former users of interactive whiteboards on external factors affecting their adoption, usage and abandonment. Computers in Human Behavior, 72, pp.733-756.

Tertemiz, N. (Is1k), Sahin, D., Can, B., and Duzgun, S. (2015). Views of primary school teachers and students about the interactive whiteboard. Procedia - Social and Behavioral Sciences, 186, pp. 1289-1297.

Tosuntaş, Ş.B., Karadağ, E. and Orhan, S., 2015. The factors affecting acceptance and use of interactive whiteboard within the scope of the FATIH project: A structural equation model based on the Unified Theory of acceptance and use of technology. Computers \& Education, 81, pp.169-178.

Tunaboylu, C. and Demir, E., 2016. The effect of teaching supported by an interactive whiteboard on students' mathematical achievements in lower secondary Education. New Trends and Issues Proceedings on Humanities and Social Sciences, 3(7), pp.74-91.

Türel, Y.K. and Johnson, T.E., 2012. Teachers' belief and use of interactive whiteboards for teaching and learning. Journal of Educational Technology \& Society, 15(1), pp.381-394.

Yang, J.Y. and Teng, Y.W., 2014. Perceptions of elementary school teachers and students using interactive whiteboards in English teaching and learning. Journal of Interactive Learning Research, 25(1), pp.125-154. 